\title{
Eg5 Kinesin-Related Motor Protein Inhibitor 4SC-205
}

National Cancer Institute

\section{Source}

National Cancer Institute. Eg5 Kinesin-Related Motor Protein Inhibitor 4SC-205. NCI

Thesaurus. Code C90557.

A small-molecule inhibitor of the human kinesin-related motor protein Eg 5 with potential antineoplastic activity. Eg5 kinesin-related motor protein inhibitor 4SC-205 selectively inhibits the activity of Eg5, which may result in mitotic disruption, apoptosis and cell death. The ATP-dependent Eg5 kinesin-related motor protein (also known as KIF11 or kinesin spindle protein-5) is a plus-end directed kinesin motor protein essential for the regulation of spindle dynamics, including assembly and maintenance, during mitosis. 